\title{
The impact of customer assisted knowledge production capacity on customer capital in a knowledge-based center
}

\author{
Mohammad Reza Zahedi ${ }^{*}$, Shayan Naghdi Khanachah ${ }^{2}$ \\ Malek Ashtar University of Technology, Iran ${ }^{1,2}$ \\ zahedy182@gmail.com ${ }^{1 *}$, shayan.en24@ gmail.com ${ }^{2}$
}

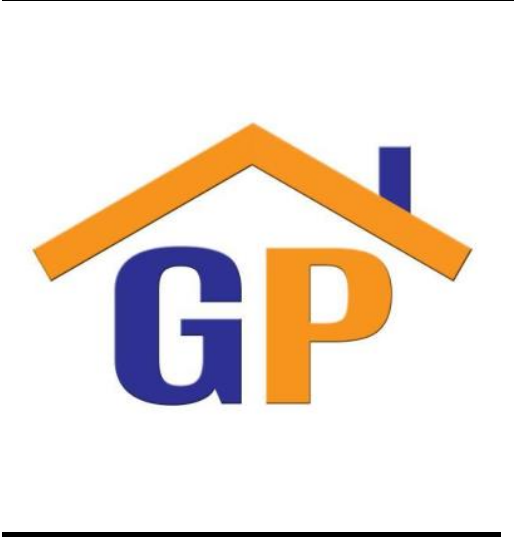

Article History

Received on 24 November 2020

Revised on 12 December 2020

Accepted on 14 December 2020

\begin{abstract}
Purpose: The purpose of this research is to investigate the impact of customer-assisted knowledge production capacity on customer capital.
\end{abstract}

Research methodology: The statistical population of the study consisted of 70 managers, researchers and experts of a scientific center and the statistical sample was counted and estimated 70 persons. The research instrument of the researcher-made questionnaire consists of six dimensions: ability to identify customer needs, create and manage a customer information system, customer loyalty, market share, cust omer service capability and target customer identification. The validity of the questionnaire was estimated $0.94 \%$.

Results: The results show that the impact of customer knowledge production capacity on all dimensions of customer capital is significant. Also, most influential among customer capital factors is customer service capability. Finally, by confirming the research hypotheses, suggestions were made based on the results of the research to improve the client's capital of the statistical society.

Limitation: This research only described Knowledge Based Center.

Contribution: Organizations realized that relying on existing knowledge alone was not enough to compete in a competitive environment, and went beyond the boundaries of their organization to acquire knowledge. Organizations considered customers as a very useful and knowledgeable resource, and activities should be done to interact with customers in leading organizations.

Keywords: Customer assisted knowledge production capacity, Customer capital, Intellectual capital, Knowledge management

How to cite: Zahedi, M. R., Khanachah, S. N. (2019). The impact of customer assisted knowledge production capacity on customer capital in a knowledge-based center. Annals of Management and Organization Research, 1(2), 107-121.

\section{Introduction}

Management sciences, like other sciences, are expanding and improving. One of the concepts that has emerged in this field is customer knowledge management. Previously, knowledge management scholars and researchers believed that in order to succeed and survive in a competitive market, only the knowledge available in the organization as a capital could be exchanged between employees and only grow in capacity, but more competitively. As market and organization need more knowledge resources organizations have realized that relying on existing knowledge in the organization alone is not enough to succeed in today's competitive environment and have expanded their organization boundaries to gain knowledge. Organizations considered customers as a very useful resource with a great deal of knowledge and activities were undertaken for knowledge interaction with customers in pioneering organizations. Over time, the benefits of interacting with customers became increasingly clear to 
organizations, and more organizations were using this knowledge resource. This further emphasized the need to provide appropriate frameworks and methods for doing so.

To this end, the topic of customer knowledge management was introduced and researchers in the field of knowledge management started to work in this field. The purpose of customer knowledge management is to share and create knowledge between the organization and its customers. The importance of knowledge in gaining competitive advantage in business processes is due to its vital role in the innovation and production of new products as one of the hallmarks of organizational competitiveness (Hislop, Bosua, \& Helms, 2018). Also, in the past, organizations have relied on knowledge resources within their organization to develop new products and innovations, but over recent decades, organizations have had to expand their knowledge resources beyond their borders (Piskun, 2019). Literature review suggests two sources are needed to provide the organization with the knowledge needed to develop new products: 1) build the knowledge required within the organization 2) acquire knowledge from external sources such as customers, suppliers, partners, competitors and institutions, academic and universities (Enqvist, 2017). External knowledge resources are often critical to the innovation process, and the ability of the organization to use this external knowledge is a determining factor for organizational innovation capabilities (Zhiqiang Wang, Wang, Zhao, Lyles, \& Zhu, 2016).

One of the concepts for using knowledge resources outside the organization is the concept of knowledge creation with the help of the customer. This concept refers to the organization's collaboration with business partners, competitors, suppliers and customers to create knowledge (Ritala, PeñalbaAguirrezabalaga, \& Saenz, 2020; Tyagi, Cai, Yang, \& Chambers, 2015). The status of customer capital is directly related to business performance, indicating that customer capital is the key determinant of converting intellectual capital to market value (Abualoush, Masa'deh, Bataineh, \& Alrowwad, 2018; Zhining Wang, Wang, \& Liang, 2014). Therefore, examining the factors that influence customer capital is important for creating a sustained competitive advantage. For this reason, the main issue of this study is to investigate the impact of customer-assisted knowledge production capacity on customer capital.

\section{Literature Review}

\subsection{The capacity to produce knowledge with the customer}

The importance of knowledge in gaining competitive advantage in business is due to its vital role in innovation and production of new products as one of the indicators of organizational competitiveness. (Al-Musali \& Ismail, 2016). Traditionally, in order to develop new products and innovations, organizations have relied on knowledge resources within their organizations, but in recent times, organizations have not been able to respond to change and have had to expand their knowledge resources beyond their borders (Rahimpour, Shirouyehzad, Asadpour, \& Karbasian, 2020).

By reviewing the literature identified two sources of knowledge and two sources of innovation to provide the knowledge needed to develop new products by the organization: Creating the required knowledge within the organization and acquiring knowledge from external sources such as customers, suppliers, partners, competitors, and institutions and academic and university (Zahedi \& Khanachah, 2020). External knowledge resources are often critical to the innovation process, and the ability of the organization to use this external knowledge is a determining factor for organizational innovation capabilities (Al-Musali \& Ismail, 2016; Zahedi \& Naghdi Khanachah, 2020). One of the newest concepts for using knowledge resources outside the organization is the concept of collaborative knowledge creation. This concept refers to the organization's collaboration with business partners, competitors, suppliers and customers to create knowledge. An organization that is capable of creating knowledge collaboratively may use this knowledge in order to gain competitive advantage (Lin, Wang, \& Kung, 2015).

Among the various players that can help the organization produce knowledge, customers undoubtedly have an important place, especially in the development of new products and services because customers know what they want, even better than the organization itself or competitors or suppliers customer knowledge is one of the factors that creates value for the organization and the customer, and today the 
effort of organizations is not only focused on "what they know" but also on "what the customer knows" (Nonaka, Kodama, Hirose, \& Kohlbacher, 2014). Opportunities and support research and development to promote innovation and new product development (Attafar, Sadidi, Attafar, \& Shahin, 2013).

Researchers suggest that customers should turn from a passive viewer into an active player in knowledge and value creation (Berkenkotter \& Huckin, 2016; Özyürek, 2007), anticipating new innovative products, existing innovative assets of the organization, better and faster response to customers' hidden needs, shorter paths to learn from mistakes, greater market share, creating a unique experience, and higher customer loyalty as the most important outcomes collaborative knowledge will be created that can create competitive advantage to be organized (Bohlin, 2005).

Taherparvar et al (2014) state that companies that utilize customer knowledge are quicker to find opportunities in the market than other companies. They also argue that customer knowledge management is a strategy by which companies upgrade their customers from passive recipients of products and services to a knowledge partner. They further divide customer knowledge collaboration with the organization into five categories (Taherparvar, Esmaeilpour, \& Dostar, 2014). Proconsumerism; team-based collaboration; mutual innovation; creator societies; and shared intellectual property. There are also studies of Lin et al. (2015) in this regard. They refer to collaborative knowledge creation as part of the organizational capability to use customer knowledge in the innovation process but do not discuss it independently (Lin et al., 2015).

Skålén et al. (2015) point out that the first problem organizations face in the process of creating collaborative knowledge with customers is identifying leading customers or customers who can offer the company valuable value propositions. Emphasizing the importance of identifying customers with valuable knowledge for the company is not only unique to Prandelli, and has always been emphasized by researchers in identifying specific customers or users who have a leadership role and engaging them in innovative processes in the organization (Skålén, Gummerus, Von Koskull, \& Magnusson, 2015).

Among these researchers, Janus (2016) and Dalkir (2017) point out that in order to succeed in the process of collaborative knowledge creation, organizations need customers who, in addition to a knowledge-sharing culture, are interested in sharing knowledge and activities. Learners are able to identify risks (Dalkir, 2017; Janus, 2016). The importance of identifying specific customers for the organization stems from an essential point that not all customers have strategic value for the organization, so the organization must select the right set of partnerships for them.

In this research, the researchers use the term customer ${ }^{1}$ service rather than other terms such as guide customers, specific customers, leader clients that are available in the literature on this subject, because organizations are choosing clients that can be part of the innovation and production process (Osterwalder, Pigneur, Bernarda, \& Smith, 2014).

Ma and Chan (2014) argue that the second problem facing the organization in the process of knowledge production is customer participation, encouraging and motivating customers to participate in the process of knowledge sharing and sharing their knowledge. In fact, engaging customers in the process of innovation and knowledge utilization and accepting them to be part of the process and presenting their knowledge is one of the major challenges facing any organization. The existing literature on corporate knowledge sharing with customers has traditionally assumed that customers are involved in the processes of innovation and development of new products and services and that their knowledge is readily available to the organization (Ma \& Chan, 2014). It has not been proven that actual experience has proven that customer engagement is not certain and that in addition to having the organization have a good plan in place, creating this partnership will also have costs for the organization, which can sometimes entail costs. This can reduce the productivity of the product development project (Torvinen \& Ulkuniemi, 2016).

Customers will agree to partner with the organization to create knowledge if they find a clear personal interest in collaborating, and it should be borne in mind that this benefit is not necessarily financial. One of the key elements that encourage customers to participate is the ability of the organization to 
build a trust-based relationship. In fact, when people trust each other, they are definitely more interested in sharing their knowledge (Hedgecoe, 2012).

When the right customers were selected by the organization and created by the organization's policies to attract them, it was their interest to collaborate with the organization in producing knowledge. In order to produce knowledge, the organization must be able to place its customers in different situations so that they can express their knowledge and it must be based on their experiences in different social roles in their real-life (Haas, 2018). One thing to note is that the organization needs to provide enough information to customers, for example about current and future opportunities and technological constraints it should provide enough information to customers (Tushar et al., 2020). One of the most important challenges facing organizations in this sector is the implicit nature of knowledge (Omotayo, 2015). Using storytelling sessions is one of the most effective and the latest ways to create the conditions for this. Storytelling is the oral expression of ideas, thoughts, personal stories and life lessons (Simmons, $\underline{2019)}$.

The importance of this issue is because some companies may be successful in creating knowledge with their customers while not being able to utilize their knowledge fully and therefore may have fewer benefits than other aspects stated in getting organized above (Kohtamäki \& Partanen, 2016). Whenever employees have a higher motivation and interest, new knowledge will be more easily absorbed and used. Creating this motivation and interest can be reinforced by some incentives for employees. In other words, the reward of collaborating with customers to produce knowledge can enhance their motivation (Gassenheimer, Siguaw, \& Hunter, 2013).

\subsection{Customer capital}

In the customer-centric arena, the main drivers of corporate profits are the customers themselves. So the question of how companies create the best customer relationship management that can keep and improve customers has been a key issue in recent years. Customer capital emphasizes the importance of customer relationship management. Customer capital as a part of intellectual capital enhances the power of customer and business communication to create value for the company.

Forte et al. (2017) add consumer capital status is directly related to business performance, indicating that customer capital is the key determinant of converting intellectual capital to market value. Therefore, measuring customer capital is critical to successfully transforming the customer relationship into an ongoing competitive advantage (Forte, Tucker, Matonti, \& Nicolò, 2017). Also, following up important customer relationship performance indicators helps evaluate customer share improvement results and ensures that customer-centric goals are achieved (Chavez, Yu, Feng, \& Wiengarten, 2016). In this Kim \& Ko (2012) believes that the development and use of customer equity indices is key to gaining a sustained competitive advantage (A. J. Kim \& Ko, 2012).

Organization needs to communicate with its customers. One of the major differences between customer capital and other components of an organization's intellectual capital is that it does not need to be formed initially. But once other funds are provided, the lack of customer capital reinforcement causes the organization to collapse. An organization that does not have a customer for its products or services will fail (Corrall, 2015).

In some cases, the core issue of customer capital is the knowledge contained in marketing channels and customer relationships that leads to the development of an organization by enhancing the competitive advantage of the company in doing business (Alonso-Montemayor et al., 2020; Lo \& Tian, 2020; Martín-de-Castro, Delgado-Verde, López-Sáez, \& Navas-López, 2011; Racela \& Thoumrungroje, 2020) In this regard, Reinartz et al (2004) propose that customer relationship activities can be divided into three stages: starting a customer relationship, and maintaining a customer relationship, and ending a customer relationship. This includes an initial evaluation of customer value, dividing customers into different groups, identifying target customers, and performing customer engagement, retention and acquisition activities (Azzam, 2014). 
Other groups consider that long-term relationships with customers represent the foundation for success in competitive markets. Therefore, customer capital consists of customer-business relationships, knowledge of marketing channels and customer relationships, the value of business-to-customer relationships (for example, current and future interest and profit shares), Know the depth of customers (penetration), scope (coverage or scope), dependency (loyalty), and profitability (Miller et al., 2019).

Fornell et al. (2016) have proposed in a study a set of metrics for customer capital, comprising five sets of indicators - market share, customer acquisition, customer retention, customer satisfaction, and customer profitability (Fornell, Morgeson III, \& Hult, 2016). Nisar \& Prabhakar (2017) have developed five key elements for evaluating customer capital, namely the type of customer, the length of time we are a customer, the role of the customer, customer support, and customer success. Each of the 5 elements has a factor called customer attraction factor that is multiplied to calculate (Nisar \& Prabhakar, 2017).

Fiano et al. (2020) consider customer capital to include processes, tools, and techniques that support customer share growth. He states that measuring customer capital is possible by measuring three key factors. He outlines three key factors 1) The effectiveness of tools and technologies and processes designed to improve the organization's relationship with customers. 2) The usefulness of tools and technologies and processes designed to improve the organization's relationship with customers.3) The rate of return on tools and technologies and processes designed to improve the organization's relationship with customers (Fiano, Mueller, Paoloni, Briamonte, \& Magni, 2020).

Murali et al (2016) state in his research that the main indicators of customer capital include customer satisfaction, customer retention, quality of products and services, average customer relationship time, and repeat orders (Murali, Pugazhendhi, \& Muralidharan, 2016). Kim et al. (2012) have examined customer capital indices from a strategic management perspective. Their findings show that the most important indicators of customer capital include new markets or channels, lost market averages, customer satisfaction, market share, customer payments, customer numbers, repeat orders, and new customer acquisition costs (T. Kim, Kim, Park, Lee, \& Jee, 2012).

Nalivaychenko et al (2018) consider customer capital as an indispensable part of intellectual capital by which it can apply the values in existing marketing channels and communications to business development. They also believe that customer capital has more impact on the realization of company values than human capital and structural capital, and this practice is becoming more and more critical (Nalivaychenko et al., 2018). Three sets of indicators are proposed to measure customer capital and this practice is becoming more and more vital. Three sets of indices have been proposed to measure customer capital, and each of these indices identifies elements that include these aspects of primary marketing capability (ability to identify customer needs, customer service capability, and build and use a database). Customer data), market share (market share, market potential, brand and brand reputation), and customer loyalty indicators (customer satisfaction, customer exit, and customer-related investment) (Bontis, Ciambotti, Palazzi, \& Sgro, 2018).

Leal-Millán et al. (2016) describe four dimensions for measuring customer capital. These dimensions include basic marketing capability (developing and managing a customer information system, ability to identify customer needs and customer service capability), customer loyalty, market share, and target customer determination. That are expressed for measuring customer capital. They also argue in their article that the scope of the customer can be extended to users of the company's products and services, and emphasize the right choice of target customers that the mistake of choosing the right partner can jeopardize the survival of the organization (Leal-Millán, Roldán, Leal-Rodríguez, \& Ortega-Gutiérrez, $\underline{2016)}$.

In sum, based on what was said in the proposal, one can consider six dimensions, the ability to identify customer needs, create and manage a customer information system, customer service capability, market share, customer loyalty, and target customer targeting for customer capital it took. 


\subsection{Conceptual model investigation}

Different dimensions can be used to investigate the knowledge-producing capacity of the customerassisted organization in this research. According to the literature review, four dimensions of ability to identify suitable customers, ability to attract suitable customers, ability to create conditions for knowledge production and ability to apply knowledge Produced for innovation.

In the field of customer equity research, more and more researchers have come up with various aspects, including the ability to identify customer needs, create and manage a customer information system, customer loyalty, market share, customer service capability, and more. Target customers are selected to measure customer capital.

After determining the two dimensions of these two main dimensions in the knowledge-based organization, the following research examines the model and examines the assumptions previously presented to determine how much the relationship expressed in this model was and the impact of the knowledge production capacity on the model. How much is the customer's help on each dimension.

Figure 1: Adapted model from research literature

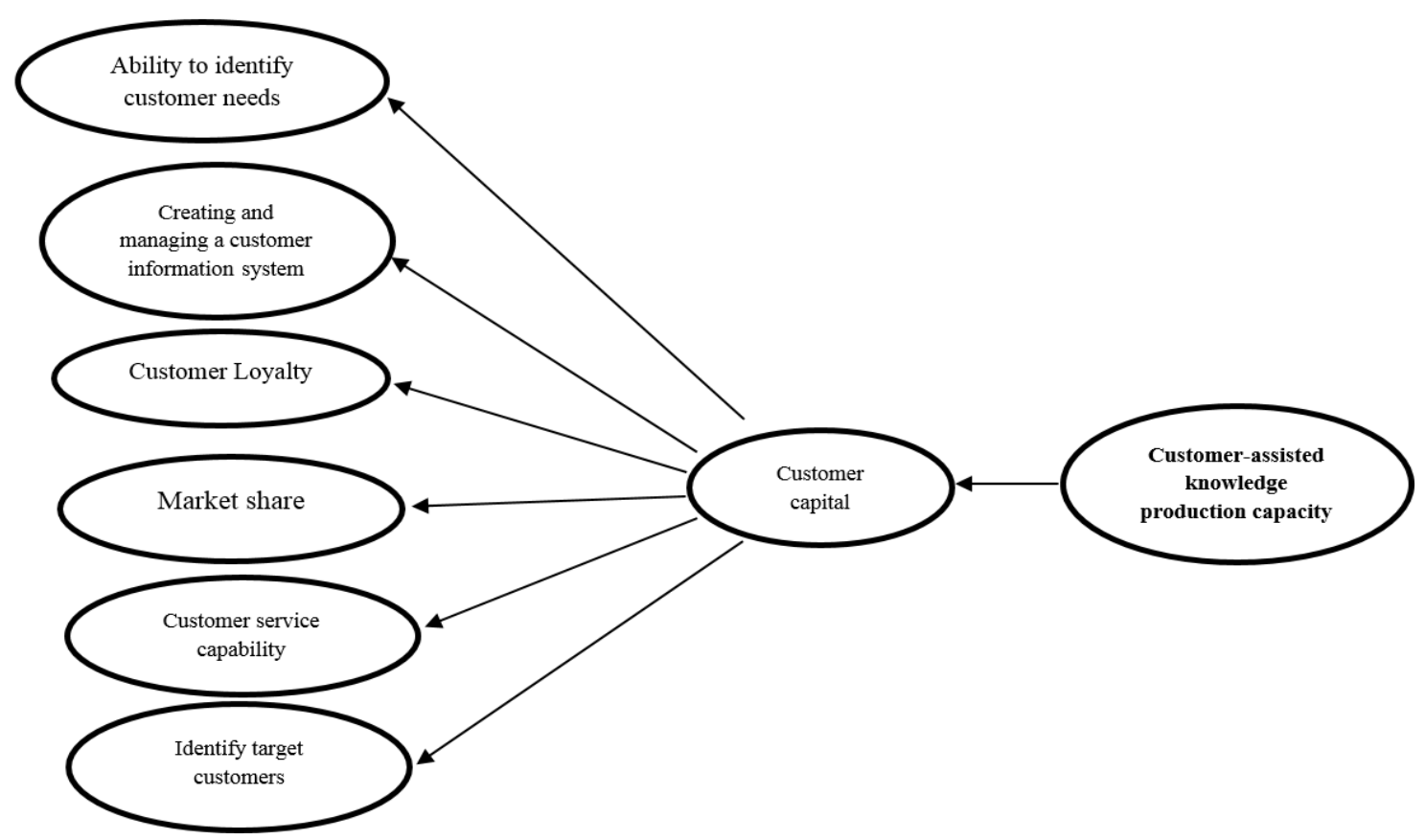

\section{Research methodology}

Purpose of this study is to promote the research results for use in the production or development of new materials, products, instruments, processes, and methods, or to improve them, this research is a developmental research. The relationship between several variables is examined. State reason it is a correlational study. Questionnaire tools have been used to measure, confirm or reject hypotheses, which include two areas of customer-centric knowledge production capacity and customer capital. Initially a preliminary list of factors was extracted and a questionnaire was asked by experts to comment on the importance and necessity of each of them. The research was approved by experts with 5 dimensions and $\mathbf{4 7}$ indices and the final conceptual model of the study was modified to Figure 2.

Table 1: Cronbach's alpha questionnaire

\begin{tabular}{|c|c|}
\hline Cronbach's alpha & number of items \\
\hline 0.96 & 47 \\
\hline
\end{tabular}


As can be seen from the Cronbach's alpha values, the reliability of the questionnaire can be stated as necessary.

Figure 2 - Final model

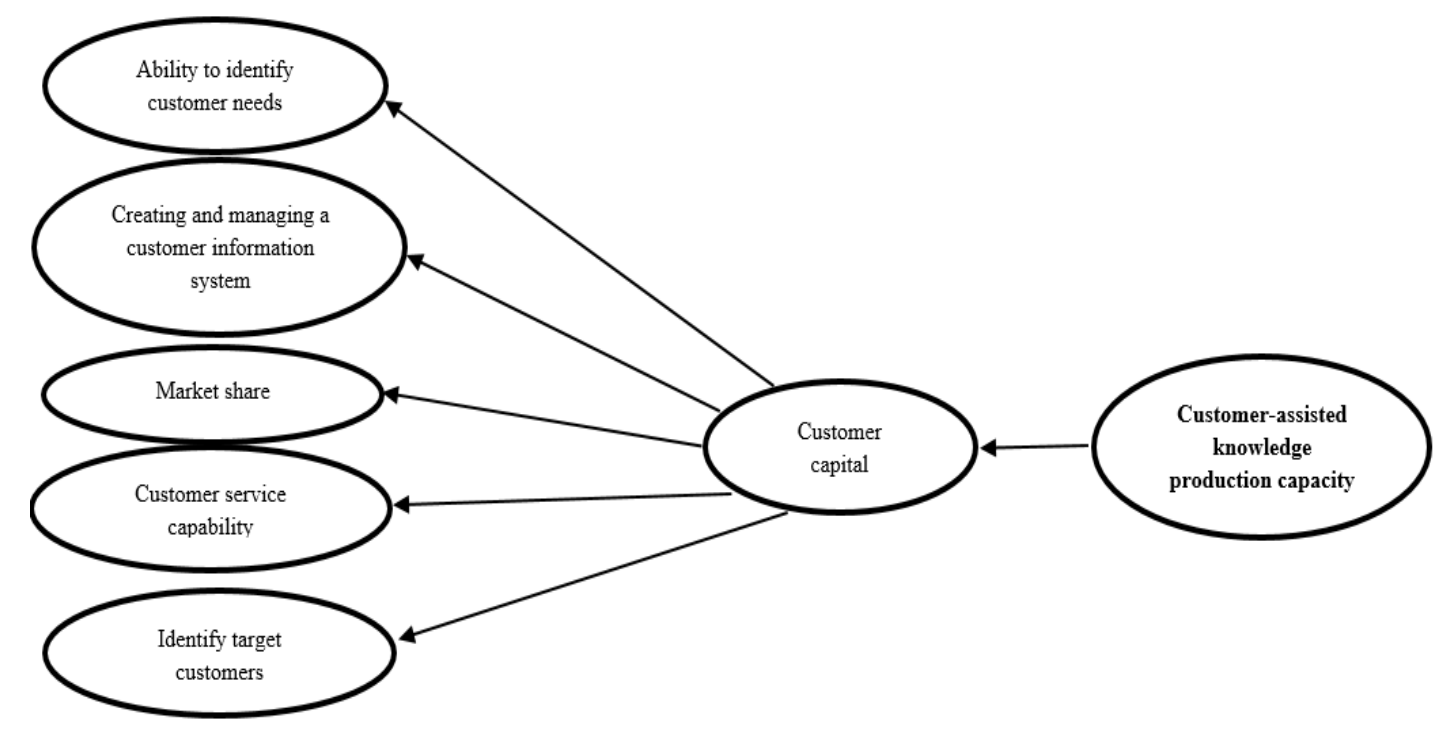

For the statistical population of this study, 70 researchers, documents and specialized interviews are informed about the fundamentals of knowledge management and customer capital in a knowledge based company. Due to the low numerical differences between the sample and the population, as well as increasing the accuracy of the whole study, a large number of studies were performed.

\section{Hypotheses}

The main hypothesis of this research is:

Customer-assisted knowledge production capacity has a significant impact on customer capital

The sub-hypotheses of the research are also:

1) Customer-assisted knowledge production capacity has a significant impact on the ability to identify customer needs

2) Customer-assisted knowledge production capacity has a significant impact on the creation and management of a customer information system

3) Customer-assisted knowledge production capacity has a significant impact on customer service capability

4) Customer-assisted knowledge production capacity has a significant impact on market share

5) Customer-assisted knowledge production capacity has a significant impact on customer loyalty

6) Customer-assisted knowledge production capacity has a significant impact on target customer. 


\section{Results and discussions}

\section{Statistical description of society}

The demographic information of the statistical population is presented in Table 2

Table 2: Demographic Information of Statistical Society

work experience

education

Gender

\begin{tabular}{|c|c|c|c|c|c|c|c|c|c|c|}
\hline 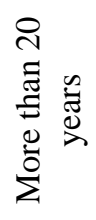 & 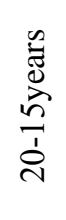 & 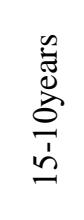 & 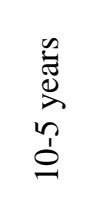 & 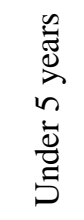 & 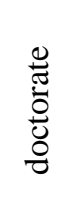 & 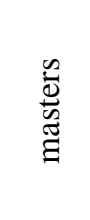 & $\frac{\frac{\tilde{0}}{0}}{\frac{\pi}{0}}$ & 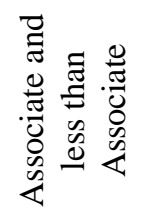 & $\begin{array}{l}\stackrel{\mathscr{U}}{\mathfrak{\Xi}} \\
\text { J }\end{array}$ & 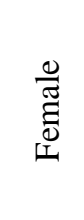 \\
\hline 10 & 6 & 10 & 31 & 13 & 2 & 17 & 45 & 6 & 51 & 19 \\
\hline$\% 13$ & $\% 9$ & $\% 14$ & $\% 45$ & $\% 19$ & $\% 3$ & $\% 25$ & $\% 64$ & $\% 8$ & $\% 73$ & $\% 17$ \\
\hline
\end{tabular}

Data analysis

For data analysis and research hypotheses, Kolmogorov-Smirnov test and regression analysis were used. These analyzes were performed using SPSS software

The Kolmogorov-Smirnov test was used to determine the normality of the research variables. The results were as follows:

Table 3: Customer Assisted Knowledge Production Capacity Variable Normality

\begin{tabular}{|c|c|c|c|c|c|c|}
\hline & & $\begin{array}{l}\text { Ability to } \\
\text { identify } \\
\text { suitable } \\
\text { customers }\end{array}$ & $\begin{array}{c}\text { Ability to } \\
\text { attract } \\
\text { customers }\end{array}$ & $\begin{array}{c}\text { Preparation } \\
\text { ability } \\
\text { Conditions } \\
\text { for } \\
\text { knowledge } \\
\text { creation }\end{array}$ & $\begin{array}{l}\text { The } \\
\text { ability to } \\
\text { apply the } \\
\text { knowledge } \\
\text { produced } \\
\text { in the } \\
\text { creation of } \\
\text { innovation }\end{array}$ & $\begin{array}{l}\text { Customer- } \\
\text { assisted } \\
\text { knowledge } \\
\text { production } \\
\text { capacity }\end{array}$ \\
\hline \multicolumn{2}{|c|}{ Number } & 70 & 70 & 70 & 70 & 70 \\
\hline Average & \multirow{5}{*}{$\begin{array}{c}\text { Factors } \\
\text { of } \\
\text { normality }\end{array}$} & 2.7618 & 2.9328 & 3.0781 & 3.1121 & 2.9897 \\
\hline $\begin{array}{l}\text { Standard } \\
\text { deviation }\end{array}$ & & 0.89589 & .85542 & 0.78054 & 0.77880 & 0.76572 \\
\hline Appropriate & & 0.162 & 0.161 & 0.146 & 0.143 & 0.126 \\
\hline Positive & & .074 & .105 & .067 & .113 & .093 \\
\hline Negative & & -.162 & -.161 & -.146 & -.143 & -.126 \\
\hline \multicolumn{2}{|c|}{$\mathrm{Z}$ test } & 1.355 & 1.344 & 1.221 & 1.195 & 1.053 \\
\hline \multicolumn{2}{|c|}{ The significance level } & .051 & .054 & .102 & .115 & .218 \\
\hline
\end{tabular}

Table 4: Customer Capital Variables Normality Test

\begin{tabular}{|c|c|c|c|c|c|c|}
\hline & $\begin{array}{c}\text { Identifyi } \\
\text { ng } \\
\text { customer } \\
\text { needs }\end{array}$ & $\begin{array}{c}\text { Create and } \\
\text { manage } \\
\text { one } \\
\text { Customer } \\
\text { Informatio } \\
\text { n System }\end{array}$ & $\begin{array}{c}\text { Ability to } \\
\text { service } \\
\text { customer }\end{array}$ & $\begin{array}{c}\text { Market } \\
\text { volume }\end{array}$ & $\begin{array}{c}\text { Custom } \\
\text { er } \\
\text { loyalty }\end{array}$ & $\begin{array}{c}\text { Custom } \\
\text { er } \\
\text { capital }\end{array}$ \\
\hline Number & & 70 & 70 & 70 & 70 & 70 \\
\hline Average & 3.3734 & 3.1073 & 3.1270 & 3.1314 & 3.1808 & 3.1808 \\
\hline
\end{tabular}




\begin{tabular}{|c|c|c|c|c|c|c|c|}
\hline $\begin{array}{l}\text { Standard } \\
\text { deviation }\end{array}$ & \multirow{4}{*}{$\begin{array}{c}\text { Factors } \\
\text { of } \\
\text { normali } \\
\text { ty }\end{array}$} & 0.70517 & 0.71004 & 0.75424 & 0.62442 & 0.57683 & 0.57683 \\
\hline $\begin{array}{c}\text { Appropria } \\
\text { te }\end{array}$ & & 0.084 & 0.118 & 0.142 & 0.113 & .106 & .106 \\
\hline Positive & & 0.073 & 0.118 & .081 & .060 & .086 & .086 \\
\hline Negative & & -0.084 & -0.110 & -0.142 & -.113 & -.106 & -.106 \\
\hline \multicolumn{2}{|c|}{$\mathrm{Z}$ test } & & 0.990 & 1.192 & .941 & 1.093 & .886 \\
\hline \multicolumn{2}{|c|}{ The significance level } & & 0.281 & 117. & .338 & .183 & .413 \\
\hline
\end{tabular}

Considering the results of the table and the significant level that all variables are more than 0.05 , it can be stated that the data assumption is not rejected.

Testing research hypotheses

Therefore, regression analysis is used to test the research hypotheses based on the results of the normal test as well as the interaction effects of the variables.

Table 5: Coefficient of determination and significance level of hypotheses

\begin{tabular}{|c|c|c|c|}
\hline Hypothesis & $\begin{array}{c}\text { The amount of } \\
\mathbf{R}\end{array}$ & $\begin{array}{c}\text { The coefficient of } \\
\text { determination }\end{array}$ & $\begin{array}{c}\text { The significance } \\
\text { level }\end{array}$ \\
\hline Main & 0.860 & 0.739 & 0.000 \\
\hline First sub & 0.604 & 0.365 & 0.000 \\
\hline Second sub & 0.644 & 0.414 & 0.000 \\
\hline Third sub & 0.853 & 0.727 & 0.000 \\
\hline Fourth sub & 0.814 & 0.663 & 0.000 \\
\hline Fifth sub & 0.653 & 0.426 & 0.000 \\
\hline
\end{tabular}

\section{The main hypothesis}

Customer-assisted knowledge production capacity has a significant impact on customer capital.

According to Table 5, the coefficient of determination of the regression model is 0.739 , so that knowledge production capacity explains $74 \%$ of customer capital changes.

Considering the significant level (0.00) that is given in Table 5 and is less than 0.05 it can be stated that the regression model is significant.

Table 6: Results of regression analysis of the main hypothesis

\begin{tabular}{|c|c|c|c|c|c|}
\hline \multirow{2}{*}{ Model } & $\begin{array}{c}\text { Standardized } \\
\text { coefficients }\end{array}$ & \multicolumn{2}{|c|}{$\begin{array}{c}\text { Not standardized } \\
\text { coefficients }\end{array}$} & \multirow{2}{*}{ t } & \multirow{2}{*}{ Sig. } \\
\cline { 2 - 5 } & Beta & Std. Error & B & & \\
\hline (Constant) & & 0.144 & 1.245 & 8.644 & 0.000 \\
\hline $\begin{array}{c}\text { Customer-assisted knowledge } \\
\text { production capacity }\end{array}$ & 0.860 & 0.047 & 0.648 & 13.872 & 0.000 \\
\hline
\end{tabular}


As it can be seen, the coefficient of impact of knowledge production capacity on customer's capital is 0.86 which is significant $(0.00)$ is less than 0.05 which can be stated as the capacity of knowledge production on capital. Customer feedback has a significant positive impact. So the main hypothesis is not rejected.

\section{Subsidiary Hypotheses}

The first hypothesis

Customer-assisted knowledge production capacity has a significant impact on the ability to identify customer needs.

According to Table 5, the coefficient of determination of the regression model is 0.653 .

Considering the significant level (0.00) that is shown in Table 5 and is less than 0.05 it can be stated that the regression model is significant.

Table 7: Regression analysis results of the first hypothesis

\begin{tabular}{|c|c|c|c|c|c|}
\hline \multirow{2}{*}{ Model } & $\begin{array}{c}\text { Standardized } \\
\text { coefficients }\end{array}$ & \multicolumn{2}{|c|}{$\begin{array}{c}\text { Not standardized } \\
\text { coefficients }\end{array}$} & \multirow{2}{*}{ Sig. } & \\
\cline { 2 - 4 } & Beta & Std. Error & B & & \\
\hline (Constant) & & 0.275 & 1.711 & 6.230 & 0.000 \\
\hline $\begin{array}{c}\text { Ability to identify customer } \\
\text { needs }\end{array}$ & 0.604 & 0.089 & 0.556 & 6.247 & 0.000 \\
\hline
\end{tabular}

As can be seen, the coefficient of impact of customer-assisted knowledge production capacity on the ability to identify customer needs is equal to 0.604 , which can be stated as significant $(0.00)$ less than 0.05 . There is a positive meaning. Therefore, this hypothesis is not rejected.

\section{The second hypothesis}

Customer-assisted knowledge production capacity has a significant impact on the creation and management of a customer information system.

According to Table 5, the coefficient of determination of the regression model is 0.414 .

Considering the significant level $(0.00)$ that is shown in Table 5 and is less than 0.05 it can be stated that the regression model is significant.

Table 8: Regression Analysis Results of Second Hypothesis

\begin{tabular}{|c|c|c|c|c|c|}
\hline \multirow{2}{*}{ Model } & \multirow{2}{*}{$\begin{array}{c}\text { Standardized } \\
\text { coefficients }\end{array}$} & \multicolumn{2}{|c|}{$\begin{array}{c}\text { Not standardized } \\
\text { coefficients }\end{array}$} & \multirow{2}{*}{ t } & \multirow{2}{*}{ Sig. } \\
\cline { 2 - 4 } & Beta & Std. Error & B & & \\
\hline (Constant) & & 0.265 & 1.323 & 4.983 & 0.000 \\
\hline $\begin{array}{c}\text { Creating and managing a } \\
\text { customer information system }\end{array}$ & 0644 & 0.086 & 0.597 & 6.937 & 0.000 \\
\hline
\end{tabular}

As can be seen, the coefficient of impact of customer-assisted knowledge production capacity on the creation and management of a customer information system was found to be 0.644 , which can be significant $(0.00)$ below 0.05 . Stated that there is a significant positive effect. Therefore, this hypothesis is not rejected.

\section{The third hypothesis}

\section{Customer-assisted knowledge production capacity has a significant impact on customer service capability}

According to Table 5, the coefficient of determination of the regression model is 0.727 .

Considering the significant level (0.00) that is shown in Table 5 and is less than 0.05 it can be stated that the regression model is significant.

Table 9: Regression Analysis Results of Third Hypothesis 


\begin{tabular}{|c|c|c|c|c|c|}
\hline \multirow{2}{*}{ Model } & $\begin{array}{c}\text { Standardized } \\
\text { coefficients }\end{array}$ & \multicolumn{2}{|c|}{$\begin{array}{c}\text { Not standardized } \\
\text { coefficients }\end{array}$} & \multirow{2}{*}{ Sig. } & \\
\cline { 2 - 4 } & Beta & Std. Error & B & & \\
\hline (Constant) & & 0.192 & 0.616 & 3.199 & 0.002 \\
\hline Customer service capability & 0853 & 0.062 & 0.840 & 13.463 & 0.000 \\
\hline
\end{tabular}

As can be seen, the coefficient of impact of customer-assisted knowledge production capacity on customer service capability was 0.853 which can be stated as significant $(0.00)$ less than 0.05 . There is a positive meaning. Therefore, this hypothesis is not rejected.

\section{The fourth hypothesis}

Customer-assisted knowledge production capacity has a significant impact on market share

According to Table 5, the coefficient of determination of the regression model is 0.663 .

Considering the significant level $(0.00)$ that is shown in Table 5 and is less than 0.05 it can be stated that the regression model is significant.

Table 10: Regression analysis results of the fourth hypothesis

\begin{tabular}{|c|c|c|c|c|c|}
\hline \multirow{2}{*}{ Model } & $\begin{array}{c}\text { Standardized } \\
\text { coefficients }\end{array}$ & \multicolumn{2}{|c|}{$\begin{array}{c}\text { Not standardized } \\
\text { coefficients }\end{array}$} & \multirow{2}{*}{ Sig. } & \\
\cline { 2 - 4 } & Beta & Std. Error & B & & \\
\hline (Constant) & & 0.177 & 1.146 & 6.473 & 0.000 \\
\hline Customer service capability & 0814 & 0.057 & .0664 & 11.572 & 0.000 \\
\hline
\end{tabular}

As it can be seen, the coefficient of impact of customer-assisted knowledge production capacity has been 0.814 on market share, which can be stated as significant level $(0.00)$ less than 0.05 . There are positives. Therefore, this hypothesis is not rejected.

\section{Fifth hypothesis}

Customer-assisted knowledge production capacity has a significant impact on customer loyalty. According to Table 5, the coefficient of determination of the regression model is 0.426 .

Considering the significant level (0.00) that is shown in Table 5 and is less than 0.05 it can be stated that the regression model is significant.

Table 11: Regression Analysis Results of Fifth Hypothesis

\begin{tabular}{|c|c|c|c|c|c|}
\hline \multirow{2}{*}{ Model } & $\begin{array}{c}\text { Standardized } \\
\text { coefficients }\end{array}$ & \multicolumn{2}{|c|}{$\begin{array}{c}\text { Not standardized } \\
\text { coefficients }\end{array}$} & \multirow{2}{*}{ t } & \multirow{2}{*}{ Sig. } \\
\cline { 2 - 4 } & Beta & Std. Error & B & & \\
\hline (Constant) & & 0.221 & 1.687 & 7.627 & 0.000 \\
\hline Customer Loyalty & 0653 & 0.072 & 0.510 & 7.107 & 0.000 \\
\hline
\end{tabular}

As can be seen, the coefficient of impact of customer-assisted knowledge production capacity on customer loyalty was 0.653 , which can be stated as significant $(0.05)$ less than 0.05 . There are positives. Therefore, this hypothesis is not rejected.

According to the results of the research, it has been found that the capacity of knowledge production with the customer has significant effect on all dimensions of customer capital. This research is important in that none of the studies previously examined directly the impact of knowledge creation capacity in the organization with the help of clients and external knowledge partners of the organization and on customer capital as a factor of intellectual capital reflecting this issue. The extent to which the organization's intellectual capital has become valuable in the marketplace has not been met. Based on the results of this research, the organization under study is a knowledge-based organization and can find 
out which of the sectors of its customer capital that can be influenced by strengthening the recommended factors and trends necessary to build the knowledge production capacity in this way. That customer capital itself has factors directly related to the market and thus the profitability of the company will be of double importance, consistent with the results (Nisar \& Prabhakar, 2017; Nurdin, 2016; Töytäri \& Rajala, 2015). Although this study showed that knowledge production capacity in this way had a significant effect on all dimensions of customer capital, but this effect was not the same in all dimensions and each with regard to their influence on existing trends in this type of knowledge production capacity. They are more or less influential in the organization. The most influential factor among customer capital factors is customer service capability. This is noteworthy because in the discussion of capacity building with the customer the most emphasis is on encouraging the organization in a variety of ways to convey to the organization what product or method to offer. They need the services above all, and this transition is different from the procedures outlined in the usual customer relationship management practices to the extent that the organization recommended to this route enables its customers to Design these trends and products. That's with the research results (Piskun, 2019; Racela \& Thoumrungroje, 2020; Rooein et al., 2020; Tavana, Abtahi, Di Caprio, Hashemi, \& Yousefi-Zenouz, 2018; G. WANG \& ZHENG, 2017; Wong, Tan, Lee, \& Wong, 2015) correspond.

The most obvious difference between the ways in which the customer-assisted knowledge creation capacity is implemented and the usual practices in the organization is the understanding of the content that customers have in mind and as long as it is effective in product design trends or approaches. Provision of services not involved cannot be transferred to the organization. Another important point in the results of this study is the high impact that this knowledge production method can have on the market size of the company. This result can be seen as replacing the interaction of the company with the right customers for the exchange of knowledge with the organization, which has a wider circle of people than stated in other methods. This expansion of people-to-people interaction undoubtedly impacts the needs of a wider range of target communities, a direct impact of which can be seen in the results of this research, which indicates an increase in market volume, which can be seen in earlier research in this regard. This issue has not been addressed.

\section{Conclusion}

The results (Bontis et al., 2018) also show that customer knowledge interaction with the company can affect their loyalty to the company's products and services, and it makes clear that customer loyalty to a product is not just feedback from their experience with that product and can be Other ways, such as building knowledge interaction and maintaining good company relationships with customers, increased this loyalty. The research results confirm this.

As expected, this system is due to its similarity in hardware with the customer information system in the organization, as well as the ability to be used as part of an integrated customer information system and obtain information from customers. Finding that existing systems are not able to have a positive impact on the customer information system in the organization. The results also indicate that this knowledge production method in the organization has a significant impact on the ability of the organization to identify customer needs because of its emphasis on understanding the hidden needs of customers in addition to the needs transmitted to the organization.

The results of this study indicate that the organization's knowledge interactions in order to produce knowledge have a significant impact on the organization's customer capital, which is a kind of output of the intellectual capital of the organization. It has a direct impact on the output of an organization's intellectual capital and can have a major impact on the success or failure of knowledge-based organizations whose intellectual capital is their primary capital. More on creating trends that lead to a gap The production capacity of the organization is to help customers in their interactions with customers and partners a deeper knowledge on the basis of their knowledge outside the organization. Developing a strategy and applying appropriate policies to safeguard the rights of the parties to this knowledge interaction from the results of these processes can have a huge impact on the success of existing processes in building this capacity in the organization. 
As recommendation; market became more competitive and the organization needed more knowledge resources, organizations realized that relying on existing knowledge in the organization alone was not enough to succeed in today's competitive environment and pushed beyond the boundaries of their organization to gain knowledge. Organizations considered customers as a very useful resource with a great deal of knowledge, and activities were conducted to interact with customers in leading organizations.

\section{References}

Abualoush, S., Masa'deh, R., Bataineh, K., \& Alrowwad, A. (2018). The role of knowledge management process and intellectual capital as intermediary variables between knowledge management infrastructure and organization performance. Interdisciplinary Journal of Information, Knowledge, and Management, 13, 279-309.

Al-Musali, M. A., \& Ismail, K. N. I. K. (2016). Cross-country comparison of intellectual capital performance and its impact on financial performance of commercial banks in GCC countries. International Journal of Islamic and Middle Eastern Finance and Management.

Alonso-Montemayor, F. J., Tarrés, Q., Oliver-Ortega, H., Espinach, F. X., Narro-Céspedes, R. I., Castañeda-Facio, A. O., \& Delgado-Aguilar, M. (2020). Enhancing the Mechanical Performance of Bleached Hemp Fibers Reinforced Polyamide 6 Composites: A Competitive Alternative to Commodity Composites. Polymers, 12(5), 1041.

Attafar, A., Sadidi, M., Attafar, H., \& Shahin, A. (2013). The role of customer knowledge management (CKM) in improving organization-customer relationship. Middle-East Journal of Scientific Research, 13(6), 829-835.

Azzam, Z. A. M. (2014). The impact of customer relationship management on customer satisfaction in the banking industry-a case of Jordan. European Journal of Business and Management, 6(32), 99-112.

Berkenkotter, C., \& Huckin, T. N. (2016). Genre knowledge in disciplinary communication: Cognition/culture/power: Routledge.

Bohlin, K. (2005). Teaching character education through literature: Awakening the moral imagination in secondary classrooms: Routledge.

Bontis, N., Ciambotti, M., Palazzi, F., \& Sgro, F. (2018). Intellectual capital and financial performance in social cooperative enterprises. Journal of Intellectual Capital.

Carayannis, E. G., Sindakis, S., \& Walter, C. (2015). Business model innovation as lever of organizational sustainability. The Journal of Technology Transfer, 40(1), 85-104.

Chavez, R., Yu, W., Feng, M., \& Wiengarten, F. (2016). The effect of customer-centric green supply chain management on operational performance and customer satisfaction. Business Strategy and the Environment, 25(3), 205-220.

Corrall, S. (2015). Capturing the contribution of subject librarians applying strategy maps and balanced scorecards to liaison work. Library management, 36(3), 223-234.

Dalkir, K. (2017). Knowledge management in theory and practice. MIT press.

Enqvist, J. (2017). Developing an understanding of users through an insights generation model: How insights about users can be generated from a variety of sources available in an organization. (Dissertation). Retrieved from http://urn.kb.se/resolve?urn=urn:nbn:se:uu:diva-331969.

Fiano, F., Mueller, J., Paoloni, N., Briamonte, M. F., \& Magni, D. (2020). Evaluating fashion retailers' intellectual capital: key money as a part of customer capital. Journal of Intellectual Capital.

Fornell, C., Morgeson III, F. V., \& Hult, G. T. M. (2016). Stock returns on customer satisfaction do beat the market: gauging the effect of a marketing intangible. Journal of Marketing, 80(5), 92107.

Forte, W., Tucker, J., Matonti, G., \& Nicolò, G. (2017). Measuring the intellectual capital of Italian listed companies. Journal of Intellectual Capital.

Gassenheimer, J. B., Siguaw, J. A., \& Hunter, G. L. (2013). Exploring motivations and the capacity for business crowdsourcing. AMS review, 3(4), 205-216.

Haas, E. B. (2018). When knowledge is power: Three models of change in international organizations. (Vol.22). University of California Press. 
Hedgecoe, A. M. (2012). Trust and regulatory organizations: The role of local knowledge and facework in research ethics review. Social Studies of Science, 42(5), 662-683.

Hislop, D., Bosua, R., \& Helms, R. (2018). Knowledge management in organizations: A critical introduction. Oxford university press.

Janus, S. S. (2016). Becoming a knowledge-sharing organization: A handbook for scaling up solutions through knowledge capturing and sharing: The World Bank.

Kim, A. J., \& Ko, E. (2012). Do social media marketing activities enhance customer equity? An empirical study of luxury fashion brand. Journal of business research, 65(10), 1480-1486.

Kim, T., Kim, W. G., Park, S. S. S., Lee, G., \& Jee, B. (2012). Intellectual capital and business performance: What structural relationships do they have in upper-upscale hotels? International Journal of Tourism Research, 14(4), 391-408.

Kohtamäki, M., \& Partanen, J. (2016). Co-creating value from knowledge-intensive business services in manufacturing firms: The moderating role of relationship learning in supplier-customer interactions. Journal of business research, 69(7), 2498-2506.

Leal-Millán, A., Roldán, J. L., Leal-Rodríguez, A. L., \& Ortega-Gutiérrez, J. (2016). IT and relationship learning in networks as drivers of green innovation and customer capital: Evidence from the automobile sector. Journal of Knowledge Management.

Lin, Y., Wang, Y., \& Kung, L. (2015). Influences of cross-functional collaboration and knowledge creation on technology commercialization: Evidence from high-tech industries. Industrial marketing management, 49, 128-138.

Lo, M. F., \& Tian, F. (2020). Enhancing competitive advantage in Hong Kong higher education: Linking knowledge sharing, absorptive capacity and innovation capability. Higher Education Quarterly, 74(4), 426-441.

Ma, W. W., \& Chan, A. (2014). Knowledge sharing and social media: Altruism, perceived online attachment motivation, and perceived online relationship commitment. Computers in Human Behavior, 39, 51-58.

Martín-de-Castro, G., Delgado-Verde, M., López-Sáez, P., \& Navas-López, J. E. (2011). Towards 'an intellectual capital-based view of the firm': origins and nature. Journal of business ethics, 98(4), 649-662.

Miller, A., Carney, M., Bosma, K., Abrams, E., Cox, C., \& Willis, A. (2019). Business models for energy entrepreneurship in emerging markets.

Murali, S., Pugazhendhi, S., \& Muralidharan, C. (2016). Modelling and investigating the relationship of after sales service quality with customer satisfaction, retention and loyalty-a case study of home appliances business. Journal of retailing and consumer services, 30, 67-83.

Nalivaychenko, E. V., Kirilchuk, S. P., Apatova, N. V., Skorobogatova, T. N., \& Boychenko, O. V. (2018). Managing Intellectual Property in Information Economy. Astra Salvensis.

Nisar, T. M., \& Prabhakar, G. (2017). What factors determine e-satisfaction and consumer spending in e-commerce retailing? Journal of retailing and consumer services, 39, 135-144.

Nonaka, I., Kodama, M., Hirose, A., \& Kohlbacher, F. (2014). Dynamic fractal organizations for promoting knowledge-based transformation-A new paradigm for organizational theory. European Management Journal, 32(1), 137-146.

Nurdin, N. (2016). The Roles of Information Technology in Islamic Bank Knowledge Management: A study of Two Syariah Banks in Palu. HUNAFA: Jurnal Studia Islamika, 13(2), 181-217.

Omotayo, F. O. (2015). Knowledge Management as an important tool in Organisational Management: A Review of Literature. Library Philosophy and Practice, 1(2015), 1-23.

Osterwalder, A., Pigneur, Y., Bernarda, G., \& Smith, A. (2014). Value proposition design: How to create products and services customers want. John Wiley \& Sons.

Özyürek, E. (2007). The politics of public memory in Turkey. Syracuse University Press.

Piskun, K. (2019). Features of the economy of knowledge in the Republic of Belarus and the ways of its development.

Racela, O. C., \& Thoumrungroje, A. (2020). Enhancing export performance through proactive export market development capabilities and ICT utilization. Journal of Global Marketing, 33(1), 4663. 
Rahimpour, K., Shirouyehzad, H., Asadpour, M., \& Karbasian, M. (2020). A PCA-DEA method for organizational performance evaluation based on intellectual capital and employee loyalty. Journal of Modelling in Management.

Ritala, P., Peñalba-Aguirrezabalaga, C., \& Saenz, J. (2020). Marketing-specific intellectual capital: conceptualization, scale development and empirical illustration.

Rooein, D., Bianchini, D., Leotta, F., Mecella, M., Paolini, P., \& Pernici, B. (2020). Chatting about processes in digital factories: a model-based approach in enterprise, business-process and information systems modeling (pp. 70-84). Springer.

Simmons, A. (2019). The story factor: Inspiration, influence, and persuasion through the art of storytelling. Basic books.

Skålén, P., Gummerus, J., Von Koskull, C., \& Magnusson, P. R. (2015). Exploring value propositions and service innovation: a service-dominant logic study. Journal of the Academy of Marketing Science, 43(2), 137-158.

Taherparvar, N., Esmaeilpour, R., \& Dostar, M. (2014). Customer knowledge management, innovation capability and business performance: a case study of the banking industry. Journal of Knowledge Management.

Tavana, M., Abtahi, A.-R., Di Caprio, D., Hashemi, R., \& Yousefi-Zenouz, R. (2018). An integrated location-inventory-routing humanitarian supply chain network with pre-and post-disaster management considerations. Socio-Economic Planning Sciences, 64, 21-37.

Torvinen, H., \& Ulkuniemi, P. (2016). End-user engagement within innovative public procurement practices: A case study on public-private partnership procurement. Industrial marketing management, 58, 58-68.

Töytäri, P., \& Rajala, R. (2015). Value-based selling: An organizational capability perspective. Industrial marketing management, 45, 101-112.

Tushar, W., Saha, T. K., Yuen, C., Smith, D., Ashworth, P., Poor, H. V., \& Basnet, S. (2020). Challenges and prospects for negawatt trading in light of recent technological developments. Nature Energy, 5(11), 834-841.

Tyagi, S., Cai, X., Yang, K., \& Chambers, T. (2015). Lean tools and methods to support efficient knowledge creation. International Journal of Information Management, 35(2), 204-214.

WANG, G., \& ZHENG, Y. (2017). Production segmentation and total factor productivity of Chinese manufacturing industry: based on the analysis of number of production stages. Industrial Economics Research, (4), 7.

Wang, Z., Wang, N., \& Liang, H. (2014). Knowledge sharing, intellectual capital and firm performance. Management decision.

Wang, Z., Wang, Q., Zhao, X., Lyles, M. A., \& Zhu, G. (2016). Interactive effects of external knowledge sources and internal resources on the innovation capability of Chinese manufacturers. Industrial Management \& Data Systems.

Wong, K. Y., Tan, L. P., Lee, C. S., \& Wong, W. P. (2015). Knowledge management performance measurement: measures, approaches, trends and future directions. Information Development, 31(3), 239-257.

Zahedi, M. R., \& Khanachah, S. N. (2020). The effect of knowledge management processes on organizational innovation through intellectual capital development in Iranian industrial organizations. Journal of Science and Technology Policy Management.

Zahedi, M. R., \& Naghdi Khanachah, S. (2020). Designing and implementing a model of organizational readiness assessment to become a knowledge-based organization: Case study an Iranian research center. 